\title{
The case for an interim test-ban
}

\begin{abstract}
Against next year's review conference of the Non-Proliferation Treaty, the nuclear powers need something tangible to offer their critics. An interim fixed-term comprehensive test-ban is the best opportunity.
\end{abstract}

MR Boris Yeltsin's journey through the Western world last week was wrongly overshadowed by his failure to appear on the tarmac at Shannon airport to greet the prime minister of Ireland, Mr Albert Reynolds; it is significant, and more important, that Yeltsin had earlier told the General Assembly of the United Nations that the time had come to sign the Comprehensive Test-Ban Treaty (CTB). Yeltsin and his Russian predecessors are late converts to this cause. In the closing months of the Carter presidency in 1979, the Soviet Union was the one among the signatories of the existing Partial Test-Ban Treaty which demanded an unrealistically large number of monitoring sites in the United Kingdom to make sure that the British government was not reneging on its obligations. The requirement was enough to kill an agreement that might otherwise have been in force for the past 15 years.

Yeltsin's problem is probably the inverse of that of his predecessor-but-three, Leonid Brezhnev. In 1979, with the Cold War still being fought, keeping the other side guessing was a reasonable tactic. Now, Yeltsin is probably as embarrassed by the nuclear weapons still intact on Russian territory as are Russia's neighbours, many of them parts of the old Soviet Union. It is not simply that the authorities in Germany appear, in the past few months, to have been adept at picking up people bent on smuggling Russian fissile material out of Russia, but that the physical dismantling of Russian warheads is turning out to be a more formidable task than anybody had expected. "Cannot this problem go away?", Yeltsin may have been asking himself last week.

Sadly, for him and the rest of us, there is no way of doing that without agreement. But there is no reason why the CTB, like other important steps along the road to nuclear containment in the past decade, should not be a gradual process. The way to start is with an interim agreement, say for the next five and a half years. One benefit of such an arrangement between the three signatories of the partial test-ban treaty is that is would carry substantial weight with next year's conference of the signatories of the Nuclear Non-Proliferation Treaty, all of whom will want to know what progress has been made towards nuclear disarmament. Another is that it would put cryptonuclear powers on the spot: would clandestine developers of nuclear weapons agree to forgo tests for the next five years and, afterwards, perhaps indefinitely? That would be a neat way in which the existing nuclear powers (Yeltsin's among them) could neatly turn the tables on their critics essentially by asking that they should either quit the NPT because they cannot stomach its terms or that they should put their plans on ice for the next five years, by which time the world will be a different place. Either way, we should then know the black sheep.

\section{Conflicts of interest}

Academic institutions must be more zealous in policing arrangements between employees and industry.

THE latest twist in the great genome sequencing saga has been predictable for several years. The circumstances are described at great length in last week's issue (Nature 371, 363-364 \& 365-366; 1994) and on page 463 of this week's. J. Craig Venter's gene-sequencing organization, the Institute for Genome Research, in partnership with Human Genome Sciences Inc. and SmithKline Beecham, has stolen a march on the rest of the academic community by producing 150,000 genomic tags for human genes. Two aspects of the development rankle with the research community. First, the academic community feels upstaged. Second, people are reluctant to sign agreements with holders of this information (which is otherwise to be freely available) that will give the latter proprietary rights to inventions that may ensue. A meeting to be held in Washington this week cannot make the underlying problem go away.

The crucial question is the degree to which academic researchers can reasonably be involved with the commercial exploitation of discoveries arising from their work. It is not, of course, a novel question; it has become a clamant question only in recent decades, since the emergence in the 1970s of biotechnology as a means of making novel and useful products. Since then, many academic researchers have initiated the formation of commercial companies, sometimes doubling as officers of the companies or as consultants to them. Usually, the academic entrepreneurs end up owning part of the new company's equity.

Just how and where to draw the line between an academic researcher's academic and commercial interests is not an easy business. Academics' prime responsibilities are for the education of the young and the deepening of the general understanding of the natural world, but they are also (rightly) held to have a general responsibility for the improvement of industry, either through their publications or by providing direct assistance, as through consultancy.

None of that implies that they can be indifferent to the 